\title{
FASILITAS KREATIF DIGITAL TEKNOLOGI
}

\author{
Samuel Sukamto ${ }^{1)}$, Alvin Hadiwono ${ }^{2)}$ \\ 1)Program Studi S1 Arsitektur, Fakultas Teknik, Universitas Tarumanagara, samuelsukamto@yahoo.com \\ ${ }^{2)}$ Program Studi S1 Arsitektur, Fakultas Teknik, Universitas Tarumanagara, alvinhadiwono@ymail.com
}

\begin{abstract}
Abstrak
Tugas Open Architecture ini bertujuan untuk mengetahui dan mendesain bangunan yang bisa menerima semua golongan masyarakat, tidak melihat jabatan ataupun status dari masyarakat, percakapan/ konversasi tercipta didalamnya, dan menjadikan nya hal terpenting. Bangunan ini pun juga harus didatangi oleh masyarakat lokal dan dapat diakses oleh siapapun dan kapanpun itu. Yang terpenting dalam hal Open Architecture ini adalah bangunan tersebut harus juga membuat orang bahagia, sukacita, tidak merasa tertekan ataupun stress ketika berada didalam rancangan bangunan tersebut. Seperti yang kita ketahui, digital teknologi memberikan dampak positif serta negatif, mencari informasi, belajar, bermain, dll sebagai sisi positif sedangkan sisi negatif yaitu membuat orang melupakan sekitar nya, dan bisa terkoneksi dengan yang jauh, seperti yang dilansir oleh Sherry Turkle TED. Maka dari itu, tujuan dari proyek ini adalah agar masyarakat: Dapat mengembangkan identitas diri melalui bakat/ minat/ potensi atau interest pengguna, melalui digital teknologi, dan pastinya terciptalah percakapan antara pengguna dalam membahas interest mereka masing-masing. Sedangkan manfaat yang didapat dari proyek ini adalah masyarakat dapat mengolah dan menganalisis pengetahuan yang cukup dalam memperoleh kesetaraan dan kesepadanan didalam dunia kerja. Proyek ini akan berdampak besar bagi masyarakat kota, karena program dan fungsi yang dirancang ataupun ditentukan bisa membuat masyarakat tertarik untuk datang dan mengembangkan potensi mereka serta mendapatkan pengetahuan yang cukup.
\end{abstract}

\section{Kata kunci: Open Architecture; Sherry Turkle TED}

\begin{abstract}
The task of Open Architecture aims to know and design a building that can accept all groups of people, do not see the position or status of the community, conversation was created in it, and make it the most important thing. This building also has to be visited by local people and can be accessed by anyone and anytime. The most important thing in this Open Architecture is that the building should also make people happy, joyful, not feeling depressed or stressed when being in the design of the building. As we know, digital technology provides a positive and negative impact, access of information easily, learn something useful, play and many more becomes the positive side of digital technology, while the negative side is to make people forget about their surroundings, and able them to connect with the distant, as reported by Sherry Turkle TED. Therefore, the purpose of this project is to allow people to develop their identity through their talents/interests/ potentials of users, through digital technology, and it certainly creates conversations between users in discussing their respective interests. While the benefits gained from this project is that people can cultivate and analyze sufficient knowledge in gaining equality and in the workplace. This project will have a big impact on the community, because the programs and functions designed or determined can make people interested to come and develop their potential and gain sufficient knowledge.
\end{abstract}

\section{Keywords: Open Architecture; Sherry Turkle TED}




\section{PENDAHULUAN}

Dalam Studio Perancangan Arsitektur 8.29 ini, diberikan tema Open Architecture for The Third Place, dengan uraian program-program seperti: Commercial, Hospitality dan juga Entertainment, namun program yang akan dipilih dan nantinya dibahas lebih lanjut, adalah penggabungan program dari Commercial dan Entertainment. Dari programprogram berikut, munculah sebuah bangunan dengan fungsi suatu tempat pengembangan ide-ide atau inovasi baru yang terdapat di Kawasan terpilih. Tentu hal ini pun muncul karena hasil riset dan investigasi Kawasan serta masalah yang terdapat dalam Kawasan tersebut (mengingat bahwa Arsitektur dibuat untuk memecahkan sebuah masalah yang ada).

Fasilitas sendiri merupakan sarana untuk pelaksanaan fungsi, kreatif merupakan suatu kemampuan dalam menciptakan hal, inovasi, terobosan yang baru/ berbeda dari sesuatu yang sudah ada sebelumnya, sedangkan digital teknologi merupakan teknologi yang $t$ idak banyak menggunakan kekuatan manusia, melainkan sebuah sistem yang canggih dan pengoperasian secara otomatis. Fungsi dari sebuah Digi-Tech Creative Facility tersebut adalah sebagai pendukung masyarakat dalam mengembangkan karakter/ identitas diri dalam bakat/ minat/ potensi ataupun interest mereka masing-masing, yang pastinya memanfaatkan digital teknologi. Dalam pengembangan diri sesorang, diperlukan sarana, faktor lingkungan, pendidikan dan sebagainya yang cukup, tidak hanya itu saja, namun pengembangan diri tersebut harus dikembangkan melalui ide kreativitas, merupakan salah satu proses untuk menghasilkan hal yang baru, maupun ide, inovasi akan suatu hal atau yang dapat mempengaruhi perkembangan kreativitas individu terhadap yang harus dikembangkan. Pengembangan diri ini pun juga berpegang erat pada faktor dorongan, sarana, lingkungan, waktu dan pengetahuan/ edukasi. Edukasi sendiri adalah proses pembelajaran yang bertujuan untuk mengembangkan potensi diri pada peserta didik dan mewujudkan proses pembelajaran yang lebih baik. Edukasi ini bertujuan untuk mengembangkan kepribadian, kecerdasan dan mendidik pelajar untuk memiliki akhlak mulia, mampu mengendalikan diri dan memiliki keterampilan edukasi lebih lagi, dan semua hal itu akan lebih baik jika didukung oleh fasilitas pembelajaran yang baik. Ada 3 macam edukasi yang terdapat, edukasi formal (layaknya seperti sekolah, dengan aturan), edukasi non-formal (layaknya seperti sekolah khusus, musik, kesenian,dll) dan edukasi informal (edukasi mengenai karakter serta sifat, didapat dan diajar dari lingkungan sekitar). Dengan adanya macam-macam edukasi yang terdapat, maka lebih mudah untuk membuat fungsi atau program didalam proyek Open Architecture tersebut.

Pendidikan atau pengetahuan di zaman sekarang, zaman millenial, sangatlah dibutuhkan untuk mengimbangi dengan perkembangan teknologi, ilmu pengetahuan serta pengetahuan akan sosial. Semua hal tersebut dibutuhkan masyarakat supaya bisa lebih maju, dalam taraf ekonomi, pendidikan serta juga dapat membuat masyarakat mempunyai pengetahuan yang baik yang nantinya bisa dipakai dalam dunia kerja. Tanpa pendidikan yang cukup, banyak masyarakat tidak bisa bekerja sehingga membuat masyarakat tersebut menjadi pengangguran, dan tentunya hal ini akan berdampak negatif bagi sebuah Kota. Namun dibutuhkan juga pengembangan diri akan seseorang, bisa dikembangkan melalui karakter, minat, bakat/ potensi, dan hal lain yang berdampak untuk membuat seseorang lebih baik lagi. Seperti contoh siswa pelajar, yang mendapatkan pengetahuan secara teori di sekolah, namun diperlukan juga pengembangan diri mereka melalui praktek ataupun hal lain yang berguna untuk membuat siswa tersebut menjadi pribadi yang lebih baik lagi, dalah hal karakter, emosi dll. Dari kepribadian yang baik, maka masyarakat sendiri akan lebih maju dan sukses dalam semua hal, ekonomi, pendidikan, sosial dan sebagainya. Hal ini pun juga berguna bagi semua masyarakat, tak terkecuali, 
bukan hanya siswa pelajar. Maka dari itu, sangatlah dibutuhkan fasilitas umum untuk mengembangkan diri seseorang menjadi lebih baik. Dibelakang berdirinya proyek Digi-tech Creative Facility, didukung \& terinspirasi oleh lansiran Sherry Turkle pada Ted " Connected, But Alone ?" dalam TED 2012, yang mengatakan, teknologi khususnya teknologi digital membawa orang lebih jauh, yang seharusnya dekat, memang orang bisa terkoneksi pada yang terjauh pun, namun orang tersebut bisa saja melupakan sekitarnya atau surrounding nya, yang membuat relasi orang terdekat menjadi jauh ...(Turkle,S 2012, "Connected But Alone" seminar dalam acara TED). Digi-Tech Creative Facility yang dibuat berguna untuk membuat orang berkumpul satu sama lain, bersosialisasi dan melakukan aktifitas lainnya yang berhubungan dengan minat, bakat, interest ataupun potensi mereka masing-masing dan tentunya melalui teknologi digital.

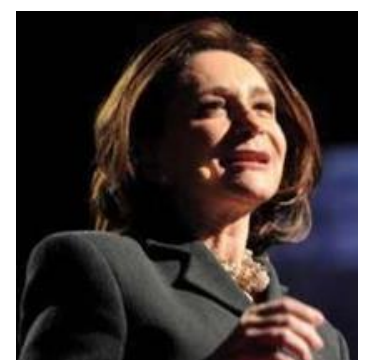

Gambar 1. Sherry Turkle TED

Sumber: Google,2012

\section{KAJIAN LITERATUR}

'Open Architecture for the Third Place'. Yaitu sebuah konsep desain Arsitektur untuk tempat ketiga , tempat ketiga sendiri adalah suatu tempat yang merupakan kebutuhan masyarakat, selain dari rumah (tempat pertama/ $1^{\text {st }}$ place) maupun tempat kerja (tempat kedua/ $2^{\text {nd }}$ place). Tempat pertama/ $1^{\text {st }}$ place ini berbicara mengenai rumah, dan memiliki ciri privat didalamnya, sedangkan tempat kedua/ $2^{\text {nd }}$ place berbicara mengenai tempat seorang beraktifitas (belajar/ bekerja) dan memiliki ciri publik serta privat. Sebelum membahas mengenai Open Architecture for the Third Place tersebut, arsitektur berkembang berdasarkan masyarakatnya, yaitu selalu direncanakan dan dirancang, bukan terbentuk dengan sendirinya. Arsitektur selalu berkembang dengan mempunyai tujuan ataupun alasan (reason). Arsitektur bukanlah benda "mati" yang sifatnya menetap, akan tetapi arsitektur mempunyai sifat yang selalu terus berkembang seiring dengan perubahan dalam masyarakat dan budayanya tersebut.

Dari pengertian "The Third Place", khususnya sebuah Place, muncul karena sebuah Space yang ada. Space adalah ruang yang dibuat oleh masyarakat ataupun yang sudah ada sebelum masyarakat membuatnya. Dari Space yang terbentuk, masyarakat mulai berdatangan dan melakukan aktifitas didalam Space tersebut, dari kumpulan aktifitas dan masyarakat sosial yang berkumpul, terciptalah sebuah Place, dimana suatu tempat yang masyarakat sosial dapat melakukan aktifitasnya ditempat tersebut (Sutanto, A., Suwardana Winata, Suryono Herlambang, (2020) Open Architecture, Jakarta, Indonesia). 


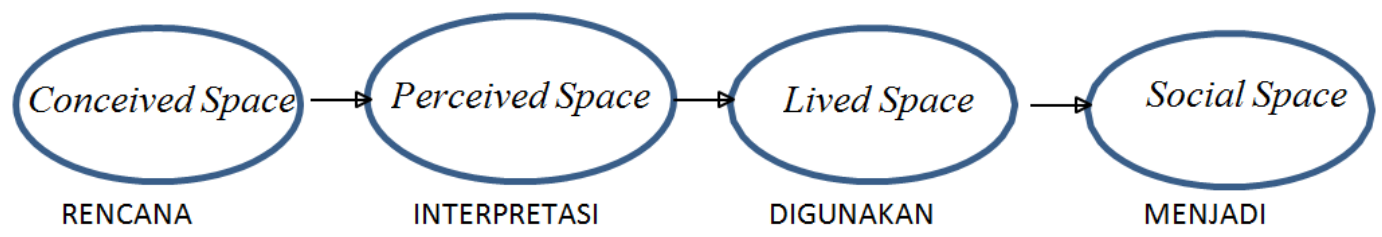

Gambar 2. Gambaran Space menjadi place

Sumber: Seminar kuliah tamu, 2020

Jika berbicara mengenai The Third Place tersebut, tempat ketiga adalah suatu tempat yang memiliki ciri gabungan zona antar publik dengan privat, yang bersifat netral, berfungsi sebagai tempat alternatif dengan melakukan berbagai aktivitas didalamnya serta menjadikan sebuah tempat yang bisa digunakan oleh siapapun dan kapanpun itu. Yang paling terpenting di tempat ketiga tersebut adalah, terjadinya konversasi/ percakapan dalam kemasyarakatan. Sebenarnya tempat ketiga itu sudah ada dimana-mana dan memiliki bentuk yang beragam sesuai dengan kehidupan dan budaya masyarakatnya.

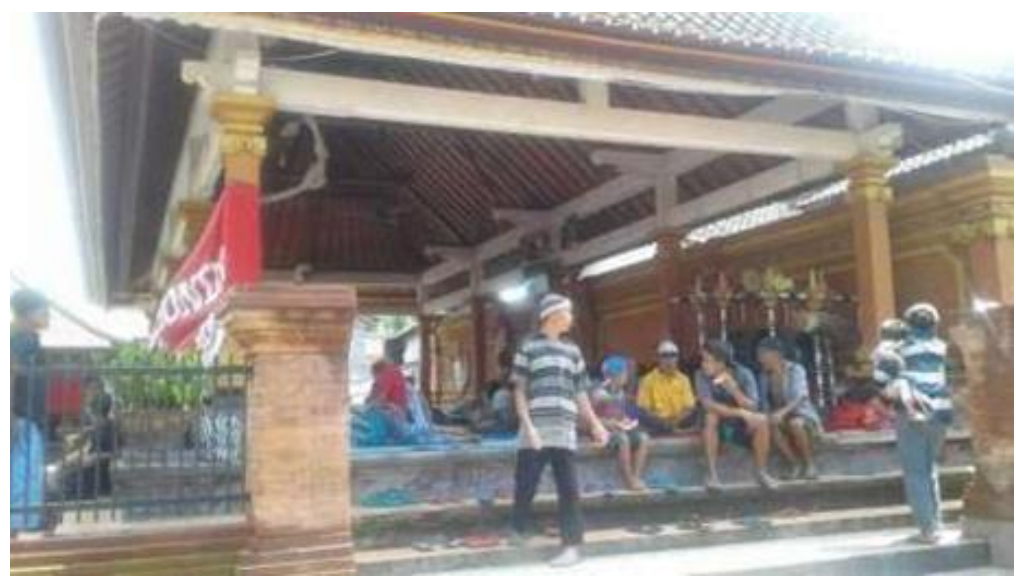

Gambar 3. Banjar/ Baledesa

Sumber: Google banjar desa, 2015

Contohnya, Indonesia memiliki tempat ketiga, seperti "Banjar" pada desa Bali, "Bale" didesa Jawa, "Lubung Intamu" atau rumah Bubungan tinggi di Kalimantan dan di berbagakomunitas lainnya, dimana masyarakat dapat berkumpul membicarakan berbagai macam hal tentang kemasyarakatannya. Di Indonesia, tempat ketiga ini biasanya hanya tempat terbuka yang diberi atap. (Buku soal TGA 8.29, 2020) Dalam seminar kuliah tamu pada mata kuliah Studio Perancangan Arsitektur 8.29 dijelaskan bahwa, Open Architecture dengan konsep tempat ketiga ini memiliki 3 sifat, antara lain : Contextuality, Openness, dan Flexibility dimana Contextuality berbicara mengenai ke identitas masyarakat lokal, dan desain bangunan harus menjawabkan permintaan atau permasalahan yang ada di dalam kemasyarakatan nya tersebut. Openness berbicara mengenai suatu bangunan dibuat tanpa melihat tingkatan ditengah-tengah masyarakat sosial, akses ruang yang dapat dicapai masyarakat dengan mudah, dan terjadi pertukaran informasi. Sedangkan Flexibility berbicara mengenai kebebasan dari masyarakat untuk melakukan aktivitas didalam ruang yang tersedia, dapat mencurahkan emosi dan diri sendiri kedalamnya. 

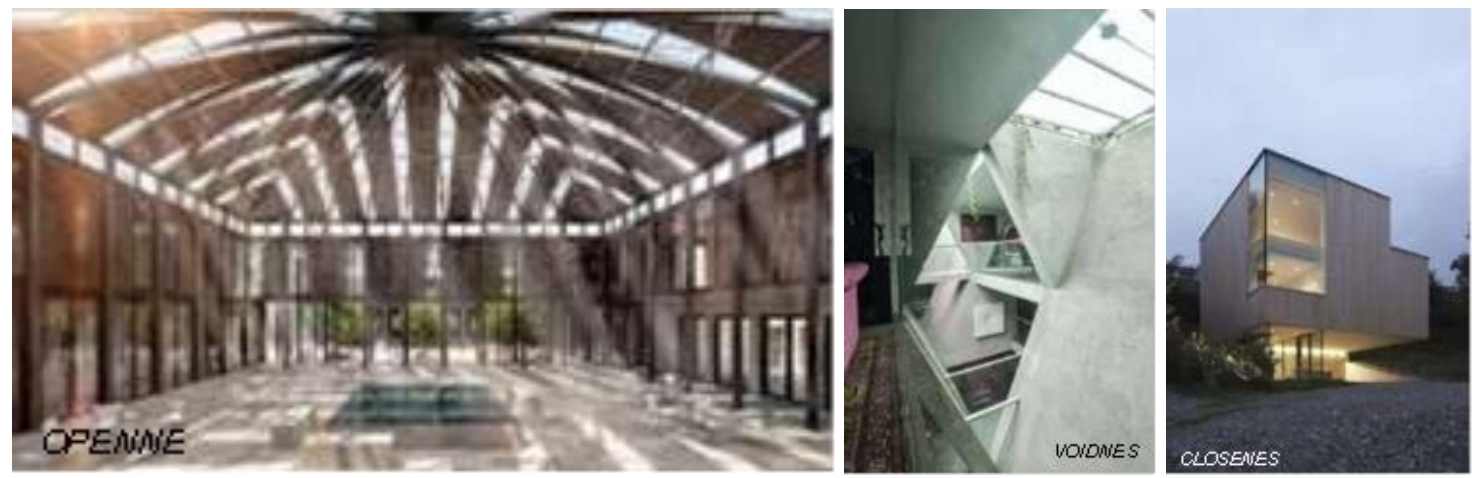

Gambar 4. Open Architecture

Sumber: Google.2020

Tentu hal yang dijelaskan diatas menimbulkan masalah, antara lain, masalah penggabungan antar ruang publik-private, keterbukaan-tertutup-kekosongan (openness, closeness, voidness), dan mempersulit dalam mendesain untuk interior, exterior, ataupun dalam sebuah space dan place. Keterbukaan adalah program yang terbuka terhadap apapun, aktivitas, pengguna, fungsi dan lain-lain, biasanya berbicara mengenai plaza. Sedangkan tertutup membicarakan kepivate-an suatu ruang, ada batasan program yang bersifat individual dan jelas. Kedua program atau konsep ini selalu dipisahkan dengan jelas, akan tetapi pada Open Architecture, kedua progam konsep ini dipertemukan sehingga diperlukan pendekatan desain dalam menyelesaikan permasalahan nya tersebut.

Open Architecture for The Third Place jika dihubungkan dengan perkotaan, merupakan tempat ketiga bagi masyarakat Kota, dimana berfungsi sebagai ruang antara, ruang yang bukan sebagai tempat tinggal (home) dan bukan tempat sebagai tempat kerja(work). Tempat ketiga adalah sebuah program yang akan membantu masyarakat Kota agar bersifat humanis, terbuka, dinamis dan produktif. Open Architecture merupakan sistem yang terbuka dan mampu beradaptasi dengan kepentingan terpilih (selected). Masalah-masalah yang terjadi dari masyarakat Kota dapat di pecahkan atau dilakukan pendekatannya melalui rangkaian pendekatan desain dan juga strategi perancangan. Open Architecture menjadi kesempatan bagi arsitek untuk menciptakan sebuah platform arsitektur yang dapat dikombinasikan dengan berbagai macam keadaan dan kondisi masyarakat, dalam hal ini masyarakat perkotaan Jakart a atau Kota besar lainnya.

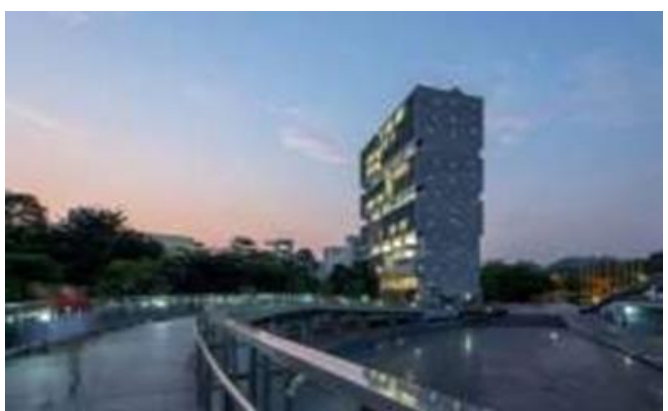

Gambar 5. Li Hu Open Architecture Design Sumber : Li Hu architect design 2017

Menurut ahli Arsitek China Li Hu mengatakan bahwa "arsitek selalu mencoba untuk menciptakan ruang dengan ekspresi. Arsitektur bukan hanya bangunan dan objek. Bisa jadi jika kita berbicara tentang arsitektur biasa-biasa saja, akan tetapi arsitektur yang baik memancarkan emosi. Puisi, kegembiraan, Spirit ualitas, inklusivitas, keterhubungan." Open Architecture adalah suatu bangunan yang manusia atau masyarakat bisa mencurahkan 
ekspresi ataupun emosi yang ada kedalamnya. Hu, 2019, "Architecture Is A Hope": A Conversation With $\mathrm{Li} \mathrm{Hu}$ Of Open Architecture" dalam website : https://www.archdaily.com/912438/ architecture-is- hope-a-conversat ion- with-li-hu-of-openarchitecture, 2019.

Seperti yang kita ketahui, digital teknologi adalah teknologi yang tidak banyak menggunakan kekuatan manusia, melainkan sebuah sistem yang canggih dan pengoperasian secara otomatis. Hal tersebut (teknologi) juga dibutuhkan oleh masyarakat, untuk menyesuaikan keseharian hidupnya, dan teknologi tersebut digunakan dengan tidak memandang status masyarakat (semua orang memerlukan teknologi), hal ini sama dengan teori Open Architecture, dimana ada suatu bangunan yang bisa menerima semua orang tanpa melihat jabatan, status dll. Dengan bantuan teknologi, khususnya digital teknologi, masyarakat akan lebih tertarik serta mudah untuk mendapatkan terobosan/ ide-ide baru (kreatifitas), dan tentunya hal ini akan meningkatkan bakat/ potensi yang pengguna ingincapai. Jika kita telurusi lebih dalam lagi, Digital teknologi tentunya mempunyai dimensi, aturan dan penyesuaian yang harus ditentukan ke dalam bangunan. Ada beberapa standar digital teknologi yang didapat dari hasil riset, dan inipun adalah hasil yang dibuat kedalam bangunan Digi-Tech Creative Facility tersebut, yang bisa dilihat jelas di lampiran pada laporan perancangan

\section{METODE}

Metode yang akan dipakai sebagai perancangan proyek Open Architecture for The Third Place tersebut, adalah Metaphor, adalah kiasan atau ungkapan bentuk, diwujudkan dalam bangunan dengan harapan akan menimbulkan tanggapan dari orang yang menikmati atau memakai karyanya. Tipe Metafora yang dipakai:

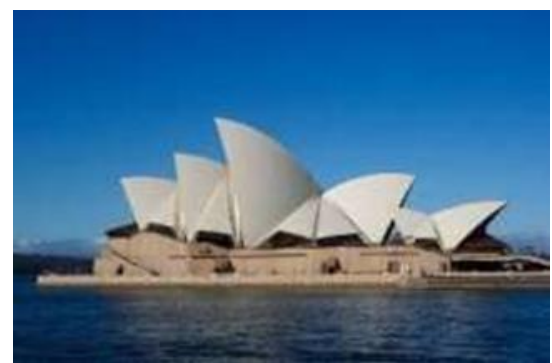

Gambar 6. Sydney Opera House

Sumber : Opera House Australia,2020

Combined Metaphor (metafora kombinasi), merupakan penggabungan Intagible Metaphor dengan Tangible Metaphor, yang membandingkan suatu objek visual dengan yang lain dimana mempunyai persamaan nilai konsep dengan objek visualnya. Seperti halnya Sydney Opera House merancang dengan membayangkan layar kapal dan nantinya dihadirkan kedalambangunan. Metode Metaphor dipilih untuk menjadi konsep desain bangunan Open Architecture for The Third Place tersebut karena, strategi ini diperlukan untuk membuat desain bangunan yang mencirikan gerakan air atau ombak ( hal ini bisa dibuat desainnya dari permainan dinding, atap, lantai ataupun ornamen-ornamen lainnya. Hal ini diperlukan untuk mengedepankan dan juga menguatkan LOCl, yaitu hal yang mencirikan/ menggambarkan Kawasan tersebut, sehingga masyarakat bisa dengan mudah mengingat Kawasan tersebut. LOCI Kawasan terpilih, sangat berdekatan lokasi nya dengan perairan laut yang bisa menjadi nilai tambah atau konsep desain pada proyek Open Architecture for The Third Place tersebut.

\section{Teori Perancangan}

Teori yang dipakai untuk merancang bangunan Open Architecture tersebut dengan fungsi fasilitas kreatif digital teknologi adalah, "Form Follow Fiction", dimana teori ini menjelaskan 
bagaimana bangunan dan masyarakat saling menaskahi atau membentuk suatu sikap/ karakter yang terdapat. Teori ini ditemukan oleh arsitek asal swiss, bernama Bernard Tschumi. la juga mengatakan bahwa "Form Follow Fiction" ini adalah suatu metode perancangan dimana bentukan arsitektur mengikuti sebuah cerita/ fiksi maupun imaginasi. , "Why Great Architects Should Tell a Story"(TED). Schreen, O, 2016, "Why Great Architects Should Tell A Story"dalam acara seminar TED, 2016.

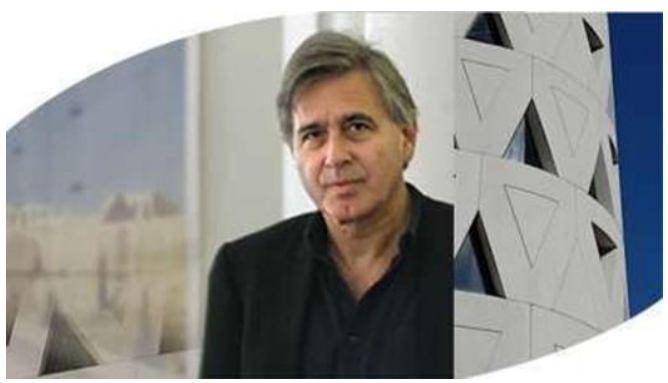

Gambar 7. Bernard Tschumi Sumber: Form Follow Fiction, 2016
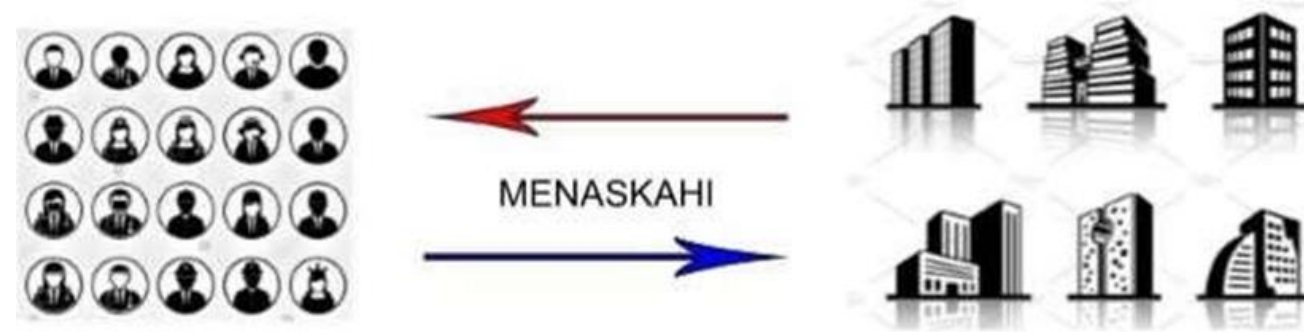

Gambar 8. Bangunan \& Masyarakat saling menaskahi

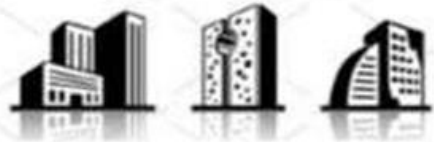

Sum ber : Google, 2020

Jika teori perancangan ini dihubungkan dengan Open Architecture, maka bisa dibilang bahwa bangunan dengan fungsi fasilitas kreatif digital teknologi ini menceritakan perbedaan hidup 'si kaya' dan 'si miskin', dimana bangunan ini bisa menggabungkan mereka kedalamnya dengan fungsi-fungsi atau program yang dirancang sedemikian rupa guna untuk menghubungkan mereka dan terciptalah place, dimana masyarakat berkumpul dan bersosialisasi satu dengan yang lain.
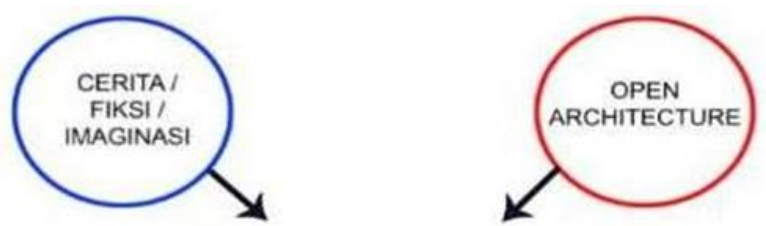

HIDUP ANTARA MASYARAKAT
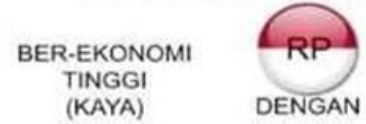

BER-EKONOM RENDAH (MISKIN)

Gambar 9. Teori Form Follow Fiction dihubungkan dengan Open Architecture Sumber : Penulis, 2020

Dibalik sebuah desain Digi-Tech Creative Facility, menceritakan pula pengibaratan akan ke-4 karakter manusia, dan dipakai sebagai pengibaratan saja, cth, sanguin (tipe orang yang senang, mudah bergaul, fun) diibaratkan dengan area bangunan pleasuring / menyenangkan pengguna. 

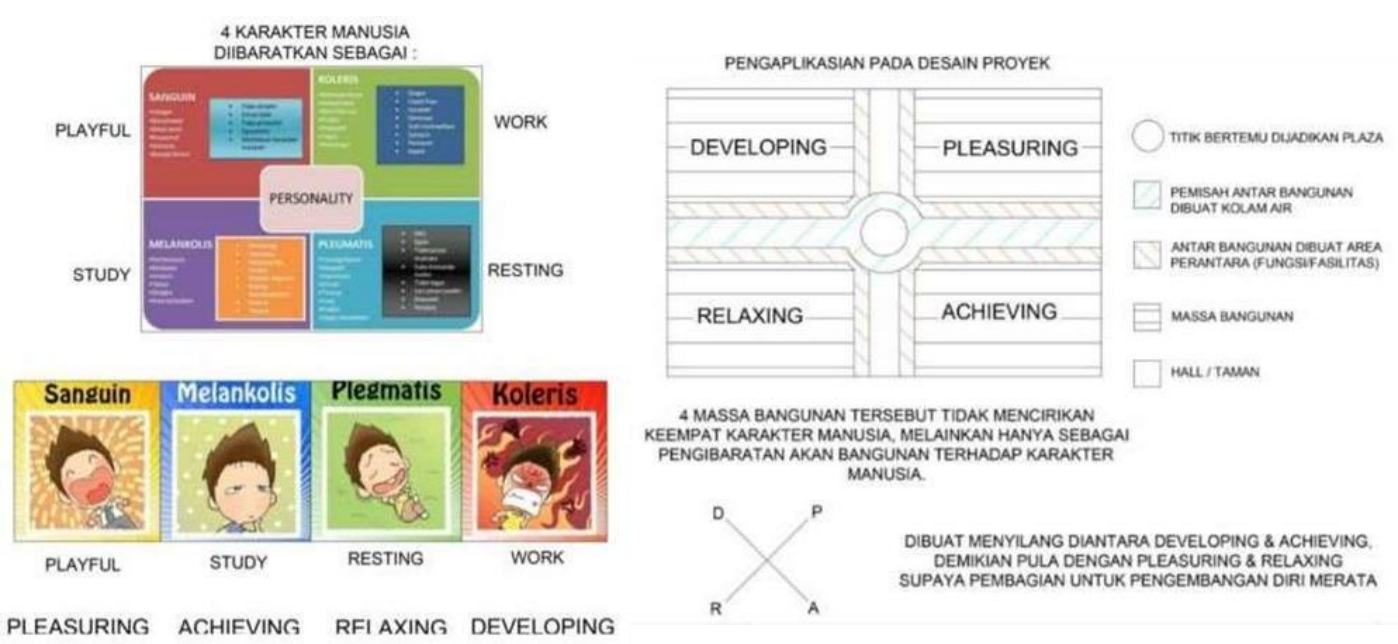

Gambar 10. Pengibaratan ke-4 karakter manusia terhadap area bangunan Sumber: Penulis, 2020

"LIGHT AS AN INSTRUMENT OF HOPE" As Building Concept Design (Designcurial.Com, Paul Nulty) Paul nulty, Light As An Instrument Of Hope, 2020, diambil dari web :

http:/ / www.designcurial.com/ news/ light-an-instrument-of-hope-7889683. Digital teknologi mempunyai partikel yang beperan penting, yaitu adanya pencahayaan, maka permainan cahaya juga dijadikan konsep desain untuk Digi-Tech Creative Facility tersebut. Permainan pencahayaan pada bangunan Digi-Tech Creative Facility, ditemukan pada dinding yang bergelombang atau curved, dimana cahaya tersebut diproyeksikan ke dinding.

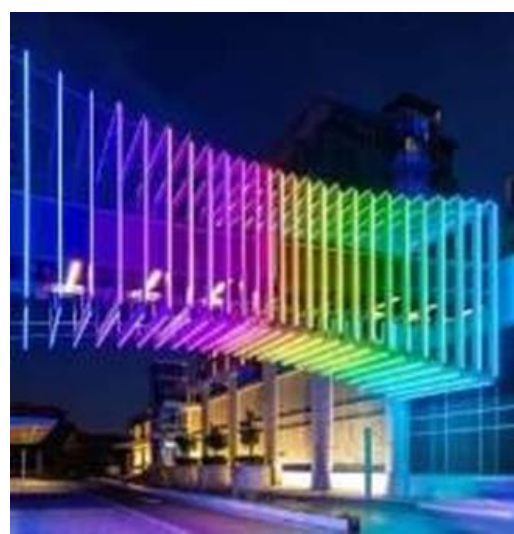

Gambar 11 Light As An Instrument Of Hope Sumber : Design Curial,2020
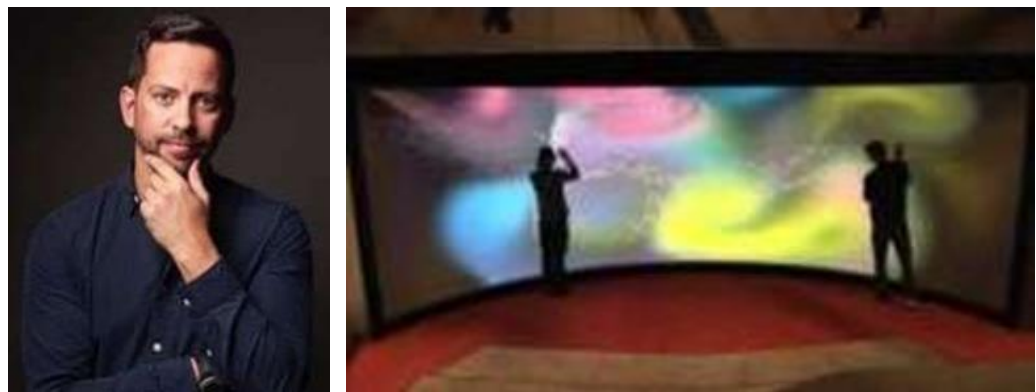

Gambar 12 Paul Nulty (kiri),

Gambar 13. Digital Interactive Area (kanan)

Sumber : https://www.nultylighting.co.uk/blog/light-an-instrument-of-hope-paul-nulty-design-curial/ 

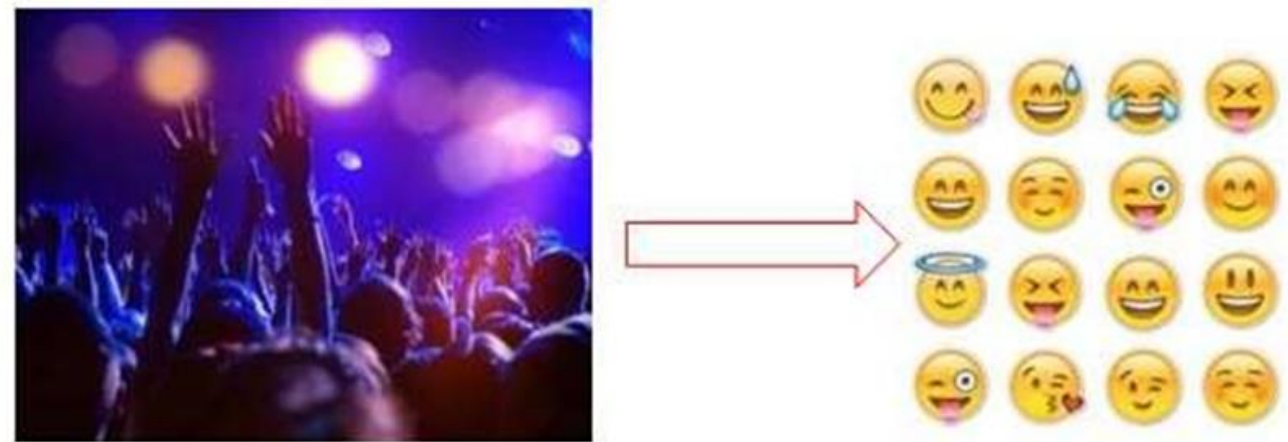

Gambar 14. Gambaran berkumpulnya masyarakat membuat sukacita atau kebahagiaan Sumber: google, 2020

Dengan adanya permainan pencahayaan, masyarakat akan merasakan kehangatan, kebahagiaan, dll, yang tentunya memberikan dampak positif bagi masyarakat, mereka bisa berkumpul dan bersosialisasi satu sama lain lebih lagi, dari efek permainan cahaya. Terlebih lagi permainan cahaya, bisa mengubah perasaan yang sedih mnejadi senang/ sukacita, cth, akibat pandemi, banyak orang harus berjuang melewati kesedihan bagi mereka yang kehilangan ataupun terdapat masalah lainnya. Lebih jelas lagi, tidak hanya masyarakat sebagai contohnya yang bisa dikumpulkan akibat adanya pencahayaan, binatang, seperti ikan dll berkumpul jika adanya sumber pencahayaan pada malam hari.

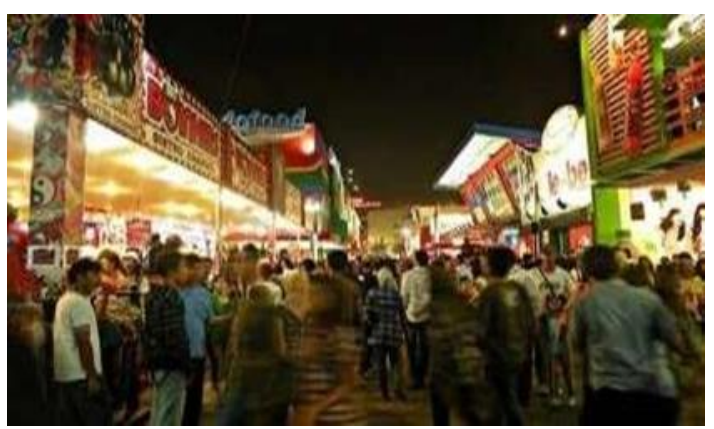

Gambar 15. Gambar masyarakat berkumpul Sumber: Google, 2020

\section{DISKUSI DAN HASIL}

Program yang terpilih adalah gabungan antara Commercial dan Entertainment, yang berhubungan erat dengan jual beli maupun jasa dan berkaitan dengan fungsi fasilitas kreatif berbasis digital teknologi guna mengembangkan bakat / minat / potensi masyarakat dengan adanya kreativitas didalamnya pada Kawasan yang terpilih. Tentunya tempat tersebut berfungsi sebagai tempat untuk mendapat atau menambah ide-ide kreativitas serta mengembangkan cara berpikir si pengguna yang tentunya didasari dengan pendidikan, sarana, lingkungan dll.

Salah satu contoh sederhana dimana masyarakat bisa mendapatkan pendidikan antara lain, sekolah, perpustakaan, laboratorium dan lain-lain. Sekolah adalah salah satu sarana untuk pendidikan yang dapat memberikan banyak manfaat bagi masyarakat didik. Pendidikan di sekolah mampu mensosialisasikan anak didik untuk mendidik mereka menjadi generasi yang lebih baik. Sekolah dan perpustakaan yang diartikan disini adalah sebagai tempat mendapatkan pendidikan secara teori. Namun secara teori pun, kurang untuk menjadikan masyarakat didik mengerti jelas, maka dari itu dibutuhkan nya pembelajaran berupa praktek/ langsung, dibuatlah laboratorium/ workshop atau sejenisnya, dimana masyarakat didik bisa mempraktekan hasil teori ataupun eksperimen nya. Karena pendidikan yang diajarkan 
sekarang bukan hanya berupa teori saja, namun perlu ada praktek dan sejenisnya.

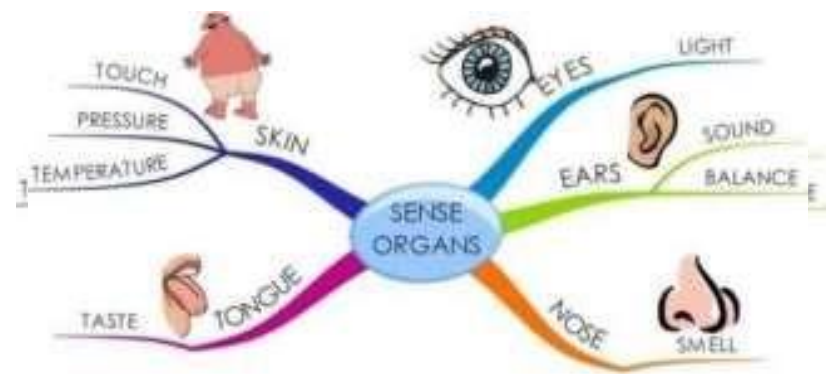

Gambar 16. Lima Panca Indera Manusia Sumber : Google, 2020

Yang dimaksud dengan cara pembelajaran yang baru adalah, masyarakat bisa mendapatkan pendidikan dengan banyak cara, bisa dengan membaca (memakai indera penglihatan), maupun mendengar (indera pendengaran), dan terlebih masyakat bisa mendapatkan pendidikan saat makan (indera pengecapan). Hal inipun timbul dari metode riset, bagaimana cara-cara orang mendapatkan pendidikan. Tentu program inipun muncul dari hasil riset yang sudah berjalan selama berada di Kawasan terpilih. Pengembangan diri seseorang akan maksimal jika didalamnya terdapat kreativitas yang didukung dengan adanya pendidikan, serta mengikuti kemajuan teknologi, seperti berkembangnya teknologi digital, maka masyarakat akan lebih tertarik dan mudah untuk mengembangkan dirinya yang bisa membuat terobosan, inovasi ataupun ide-ide kreatifnya lebih lagi. Rencana Program Ruang yang terbentuk dalam proyek fasilitas pendukung pembelajaran, antara lain:

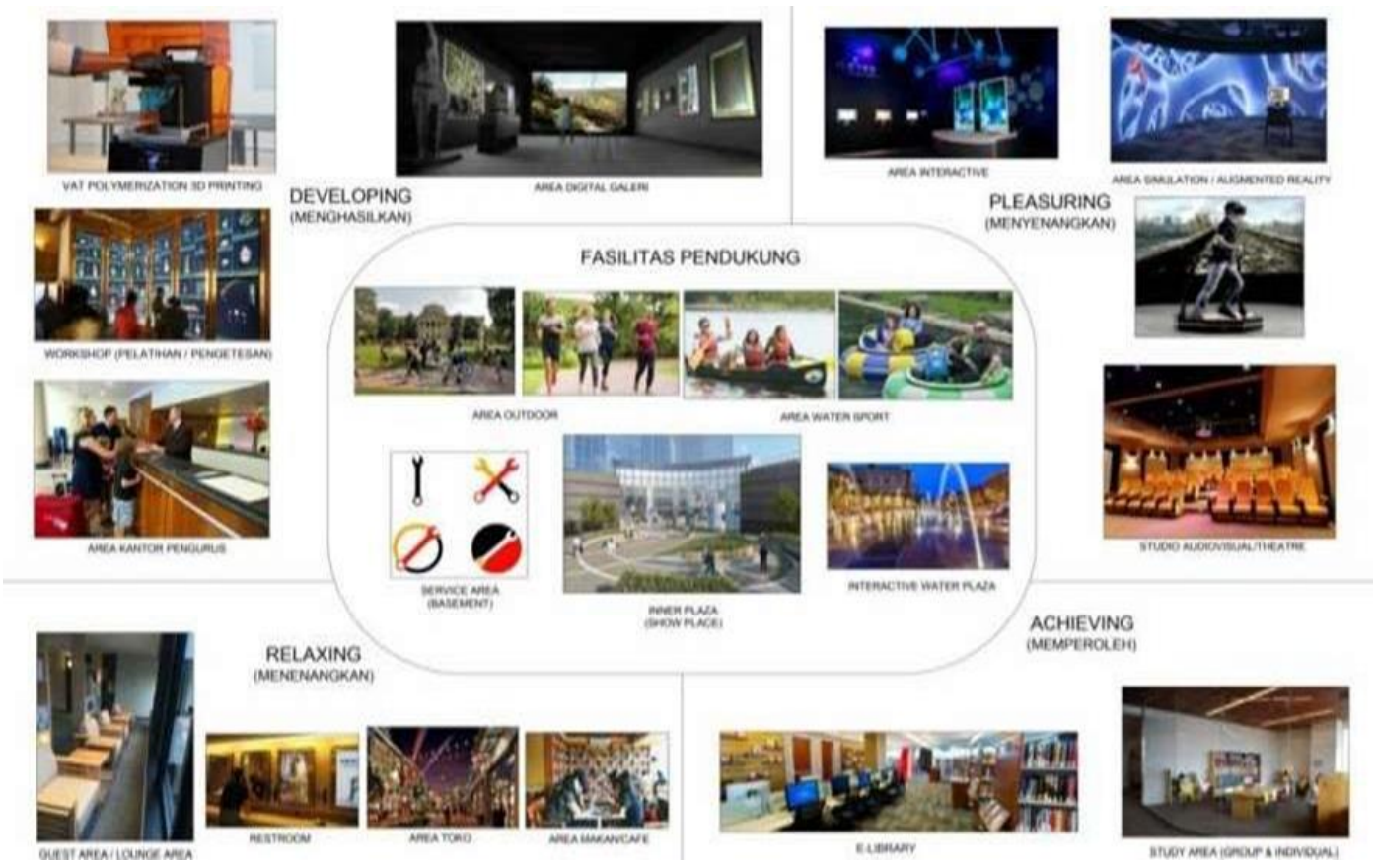

Gambar 17. Program yang dibuat Sumber : Penulis, 2020 


\begin{tabular}{|c|c|c|c|c|c|}
\hline RUANG & STANDAR LUASAN & LUAS & aTY & FUNGSU/AKTIVITAS & ZONASI AUANG \\
\hline AREA DIGTAL GAERI & $50 \mathrm{~m} 2$ & $650 \mathrm{mz}$ & เT.18เT.2 & $\begin{array}{l}\text { MEMAMEREAN HASIL DAN PEMBEL WATAN AKCN AFEA DIGTAL } \\
\text { (BERUPA DGITAL) }\end{array}$ & PUBLIK \\
\hline WOAXSHOP & $170 \mathrm{~m} 2$ & $250 \mathrm{mz}$ & IT:1) (1) $(7.2(3)$ & MENDAPATEAN EOUKASI SECARA PRACTEK LANGSUNG, KELAS-KELAS IOUUSUS & PUBUK - PRINATE \\
\hline E-UERARY & $60 \mathrm{~m} 2$ & $265 \mathrm{~m} 2$ & 1 & MENDAPATKAN EOUKAS/FEMBELWARTAN SECARA TEORI \& BERRASIS DIGITAL & puauk \\
\hline AFEA INTERACTIVE/HOLOGRAM & & $100 \mathrm{mz}$ & 1 & DEMEELaAaRAN SECARA DVETTAL, INE 30 , & SEMipusux \\
\hline AREA AUGMENTED REALTYY & & $22 \mathrm{~m} 2$ & 21 & 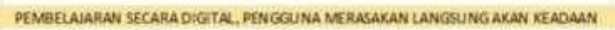 & semipuauk \\
\hline STUDio AuDiovisual & $30 \mathrm{~m} 2$ & $18 \sigma \mathrm{m} 2$ & 2 & 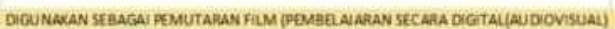 & stmipueux \\
\hline SHOWPLACE/INGER RLAZA|OPEN] & & $(50.2) 25 \mathrm{mz}$ & 1 & TEMPAT / AREA UNTUK MENVELENGGARAKCAN PENTAS SEVI & DUBuK \\
\hline GUEST AREA /NFFO (LOUNGE AREA) & & $265 \mathrm{~m}^{2}$ & 3 & AAEA AECEPTION DAN AREA UNTUK AERTEMU & pUQuK \\
\hline AREA TOKO (TOKO \& SIRKULAST) & & $\pm 209 \mathrm{mz}$ & 3 & TOKO-TOKO YANG MENUUAL KEBUTUHAN SERTA TENNOLOG & PUaLiK \\
\hline AFEA SHOP STAEET (OPEN) & & $(83+2] 41.5 \mathrm{~m} 2$ & 4 & OUTDOOR STAEET SHOP UNTIK MUSYARAKAT & PuBuK \\
\hline AREA TOLLT: & & $98 \mathrm{me}$ & 8 & AREA TORET UNTUK OENGGUNA LT.1.2) & DUBuK \\
\hline AREA CAFE & $170 \mathrm{~m} 2$ & $100 \mathrm{mz}$ & 1 & AESTORAN UNTUK MENDUKUNG KAWASAN PLUIT YANG DIKENQL DENGAN KULINER & PUauK \\
\hline STUDV AREA (GROUP S INONIOUAC). & $100 \mathrm{~m} 2$ & $300 \mathrm{~m} 2$ & เT.18:T.2 & AREA BEL LARABEEROSRUSI ATAUPUN MEETTNG AREA & puacuk \\
\hline GUDANG & & $\pm 112 \mathrm{~m} 2$ & 2 & AREA GUDANE UNTUK BARANG DUL & peivate \\
\hline RUANG PENGURUS & $100 \mathrm{~m} 2$ & $270 \mathrm{~m} 2$ & 1 & RUANG KEFENGURUSAN UNTUK BANGUNAN SERTA PENGENAR & PAIVATE \\
\hline AREA SERVIS & & $690 \mathrm{~m} 2$ & GASEMENT & 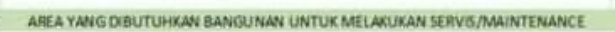 & S्रeRVIS \\
\hline
\end{tabular}

Sumber : Penulis, 2020

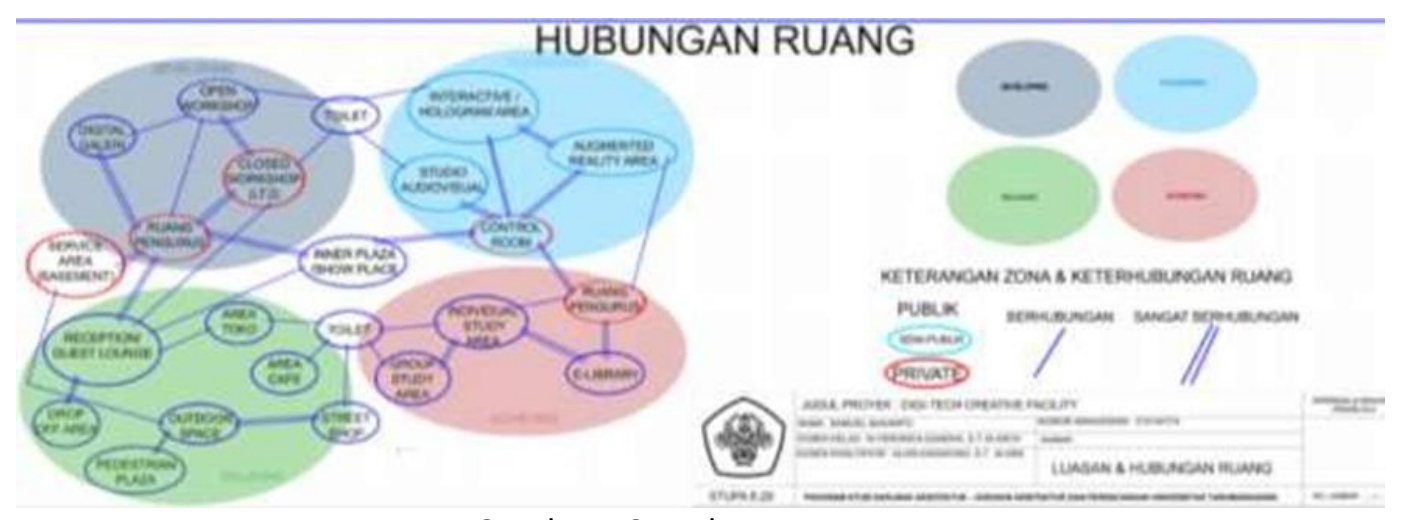

Gambar 18. Hubungan Ruang

Sumber: Penulis, 2020

Setelah membuat usulan program dan besaran ruang, masuk ke desain bangunan dimulai dengan Skema / Prosedur pembentukan rancangan bangunan berdasarkan langkah-langkah berikut :

a. Menentukan lokasi bangunan di Kawasan Pluit

Lokasi yang bersebelahan dengan sungai Pluit menjadi pilihan untuk mengedepankan konsep ombak serta LOCI Kawasan Pluit. Lokasi yang bisa mendukung adanya bangunan bertema Open Architecture tersebut, (Waduk Pluit bisa disebut sebagai area Open Architecture). Lokasi yang berdekatan dengan hunian, tempat sekolah ataupun bekerja, bisa juga diantara kedua bangunan tersebut.

b. Menentukan luas area bersih, dari pengurangan akan peraturan Kawasan, GSB, KDB dll Adanya peraturan GSS, Garis Sepadan Sungai yang berjarak minimal $10 \mathrm{~m}$ dari data yang didapat \& diriset. Mensurvey kawasan setempat, dari peraturan Kawasan, permasalahan dll. Membuat keterbedaan ketinggian lantai dri jalan ke 0.00 bangunan, setinggi $2 \mathrm{~m}$, dikarenakan Kawasan Pluit kerap kali dipermasalahkan dengan banjir atau tergenangnya air.

c. Menentukan entrance in \& out, untuk kendaraan pribadi serta loading/unloading, dan juga pedestrian lobby

Penentuan lokasi parkir kendaraan, yaitu berada pada arah utara bangunan, sudah tersedia lapangan parkir, yang bisa mendukung adanya bangunan Digi-Tech Creative Facility 
tersebut. Penentuan entrance pedestrian lobby, dan membuatnya lebih dominan / besar luasan nya dari pada entrance kendaraan, karena Open Architecture dalam tugas TGA mengutamakan lebih pada pedestrian, lengkap juga dengan fasilitas pedestrian, seperti lampu, pembatas jalan, area duduk dll

- Mengambil garis horizontal (barat-timur), dan vertikal (utara-selatan) pada lokasi bangunan, untuk dihubungkan kedalam bangunan Digi-Tech Creative Facility, (horizontal Pluit Village Mall dengan Waduk Pluit) \& (vertikal - hunian ruko elite sedang dengan hunian ruko sedang). Pembuatan Inner Plaza atau bisa dibilang sebagai titik temu tengah dari pertemuan garis vertikal \& horizontal (area titik temu masyarakat bisa dibuat sebagai show place), bisa dibuatnya pula Amphitheatre pada titik tersebut. Penggalian tanah untuk mengalirnya air sungai Pluit kedalam tapak, untuk menjadikan bangunan Digi-Tech Creative Facility tersebut lebih baik, dalam mengedepankan konsep ombak (perairan), serta LOCI Kawasan Pluit yang identik dengan perairan. Pembatasan yang jelas, antara pembagian bangunan (pengibaratan ke-4 karakter manusia) yaitu, Developing, Pleasuring, Achieving \& Relaxing. Menjadikan tantangan bagi perancangan untuk membuat air sungai Pluit / kolam urug supaya bisa disirkulasi dan menjadi jernih dalam proses-proses filtrasi Water Treatment Plant yang dibuat

d. Perancangan bangunan terhadap situasi tapak, cth lintasan matahari, aliran angin, kebisingan, kontur dll. Penyesuaian akan desain bergelombang pada atap bangunan dibuat dengan adanya alasan dan caranya tersendiri. Diesuaikan pula ketinggian bangunan pada bagian-bagian lokasi tersebut, untuk view dan aliran angin yang baik dll. Penyesuaian bukaan/ventilasi dan juga dinding tertutup pada bangunan, yang disolusikan/ditemukan dari situasi tapak tersebut, cth, terhadap view dll

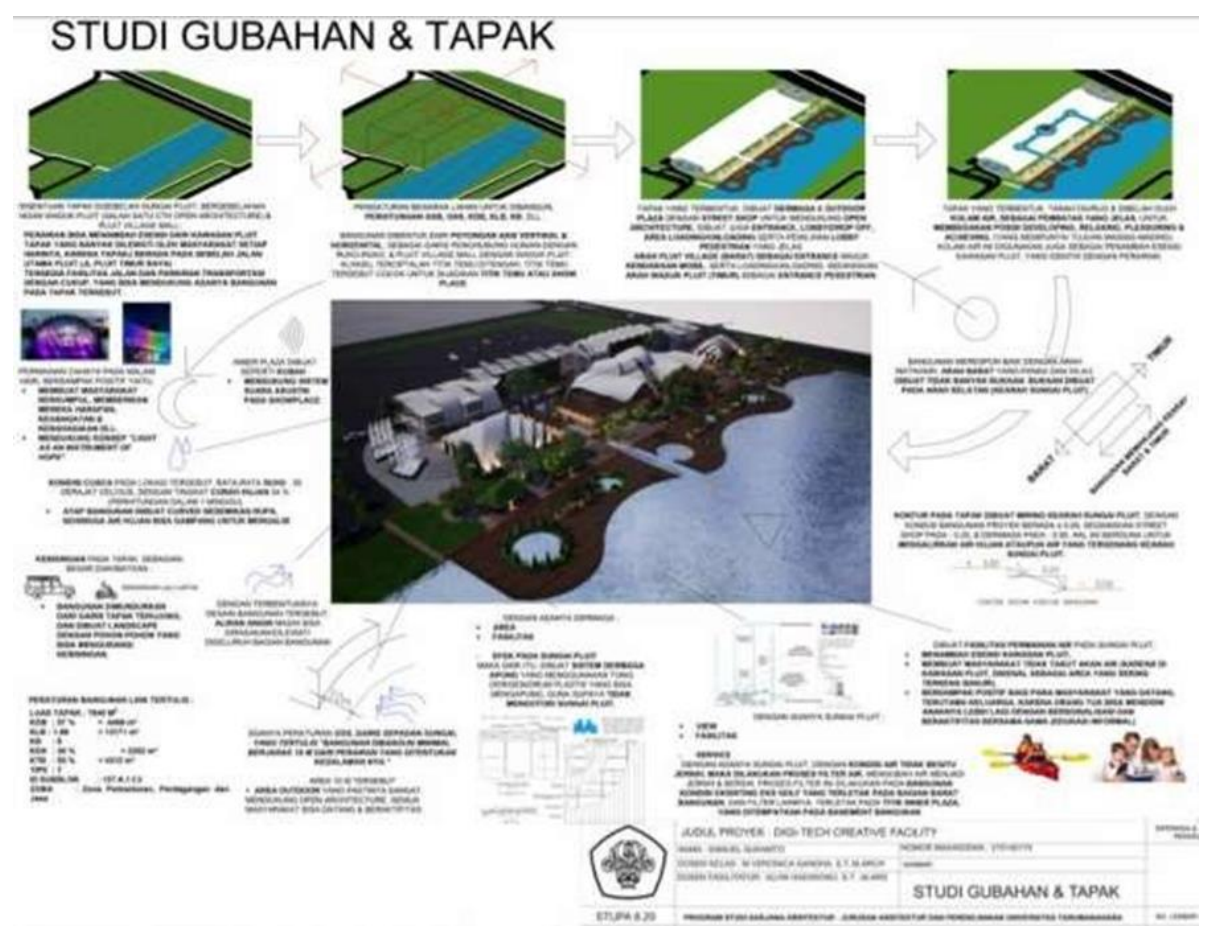

Gambar 19. Studi Gubahan \& Tapak

Sumber : Penulis, 2020 

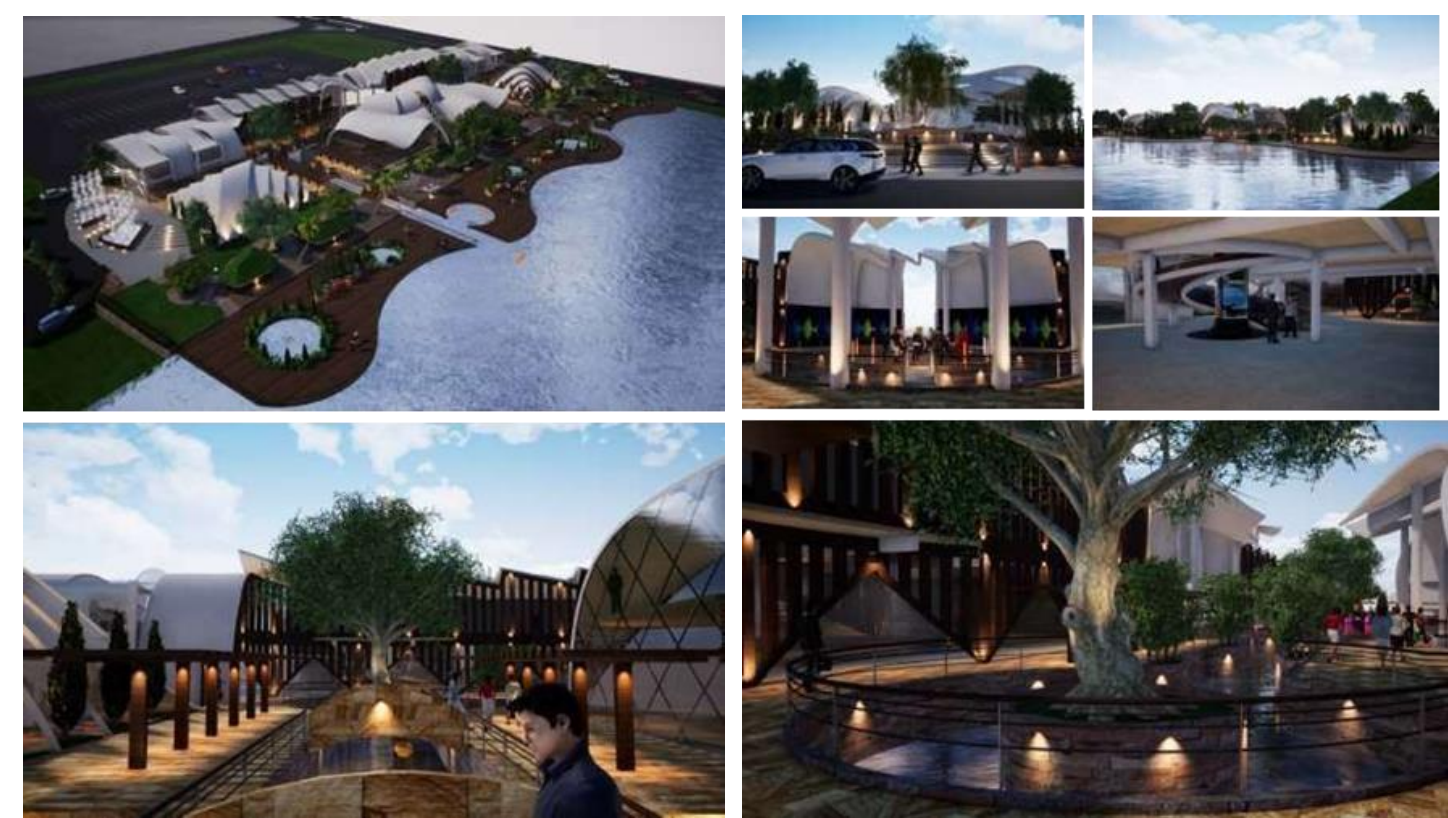

Gambar 20. Perspektif

Sumber: Penulis, 2020

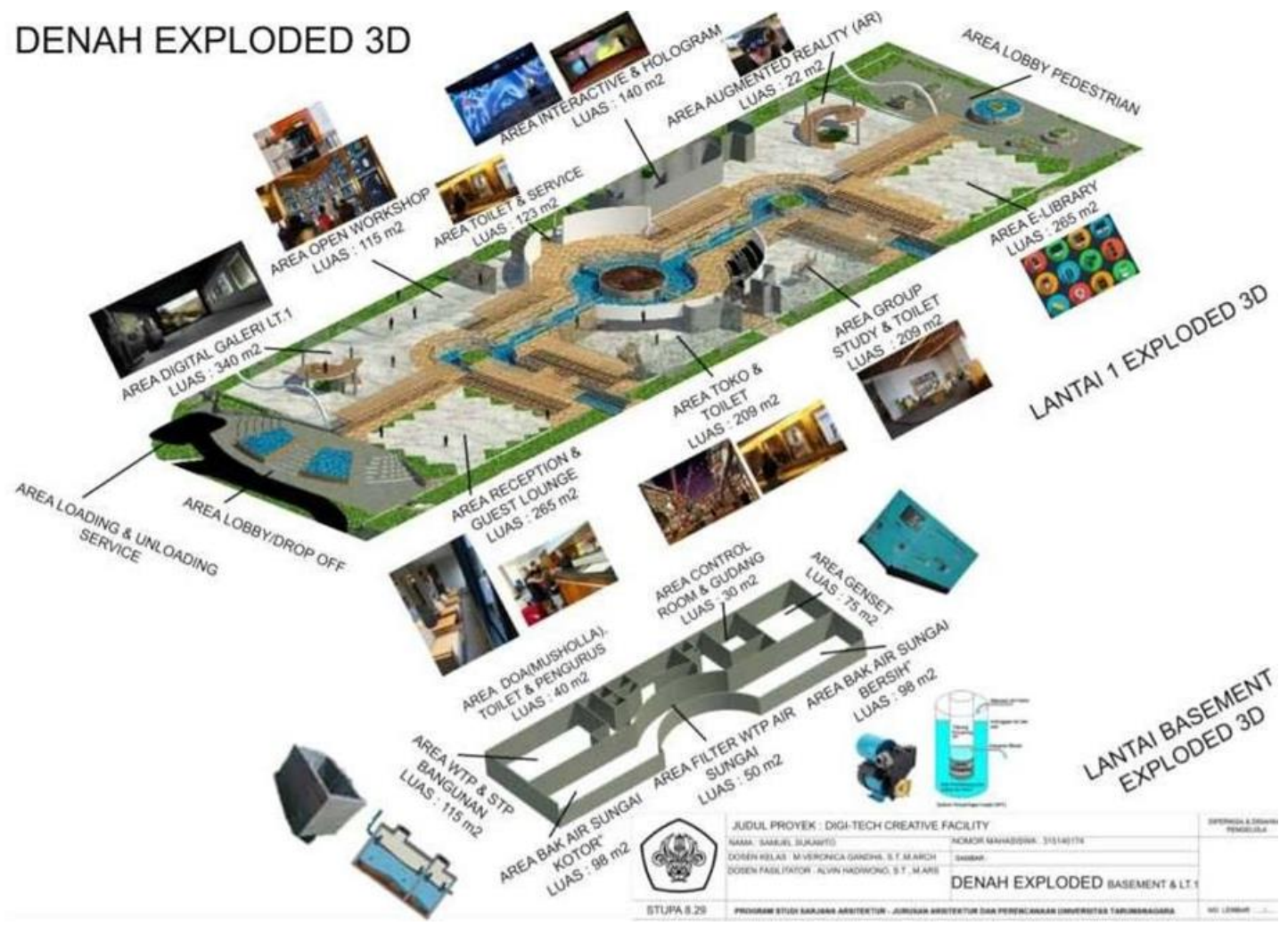




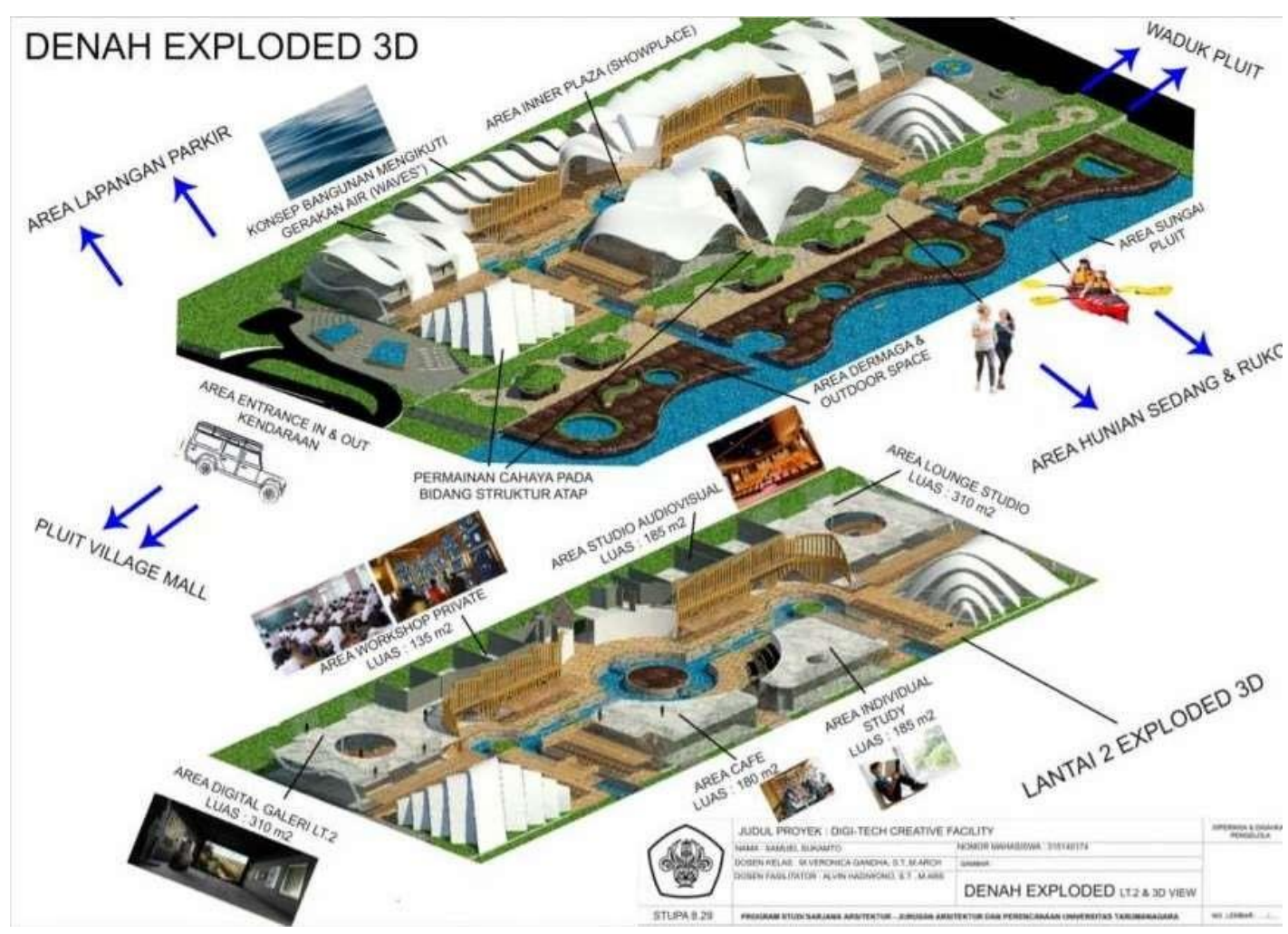

Gambar 21. Denah Exploded 3D

Sumber: Penulis, 2020

\section{KESIMPULAN DAN SARAN}

Tugas Open Architecture dengan konsep tempat ketiga ini sangat berguna untuk mahasiswa arsitek, untuk mempunyai pengalaman desain didalam sebuah bangunan yang tidak melihat tingakatan masyarakat tinggi maupun rendah, yang bisa menerima semua golongan dan usia, dalam kata lain, bangunan tersebut harus dapat digunakan oleh masyarakat untuk melakukan aktivitas, kapanpun dan siapapun itu. Juga dapat menggabungkan zona publik dengan private, ruang dalam serta ruang luar, dan juga dapat menggabungkan antara ruang terbuka dengan ruang tertutup. Saran yang bisa dibuat bagi para mahasiswa arsitek, khususnya TGA 8, adalah studi kasus lapangan akan tema Open Architecture tersebut, yang bisa membuat mahasiswa lebih mengerti / memahami lebih lagi.

Sedangkan kesimpulan yang bisa disusun adalah dari masalah/ issue yang terdapat didalam Kawasan Pluit ini bahwa banyak masyarakat dalam usia produktif", tidak tahu tujuan dan arah dalam bidang yang mereka ingin capai, serta kurangnya pendukung/ pengembangan diri seseorang melalui kreativitas bagi pengguna untuk melakukan inovasi, ide-ide yang baru. Dari masalah tersebut, dapat disimpulkan bahwa perlunya sebuah fasilitas yang digunakan untuk mengembangkan identitas diri melalui bakat/ minat/ potensi pengguna lebih lagi dimana didalamnya ada kreativitas (ide dan inovasi baru) yang masyarakat bisa gunakan untuk mengembangkan diri pengguna ,secara individu atau melalui komunitas dari masyarakat, tentunya menggunakan digital teknologi. Karena dari berkumpulnya masyarakat satu dengan yang lain, terbentuklah suatu komunitas, dan apabila komunitas tersebut mempunyai kepribadian diri yang baik dengan ide kreatif atau ilmu pengetahuan yang cukup, maka dari komunitas tersebut bisa membentuk inovasi baru guna memajukan kota, serta bangunan yang berkelanjutan untuk kedepannya. Bangunan berfungsi sebagai pengembangan akan minat/ potensi tersebut dengan adanya kreativitas ide/ inovasi baru yang didasari pendidikan juga akan berdampak positif kepada bangunan sekitar maupun masyarakat, karena dari sistem kota yang baik, pasti muncul dari sumber/ program yang membuat kota tersebut maju, dan 
sumber/ programnya bisa berarti tentang pembelajaran akan ilmu pengetahuan dan sebagainya. Jika suatu komunitas terbentuk pun yang didasari oleh pendidikan, pastinya terciptalah ide atau pengetahuan yang membuat suatu kota maju dan semakin baik.

\section{REFERENSI}

Hu, L. (2019). Architecture Is A Hope: A Conversation With Li Hu Of Open Architecture, dalam website : https://www.archdaily.com/912438/ architecture-is-hope-a-conversat ion- withli-hu-of-open-architecture, 2019

Kantor Kelurahan Pluit. Data kependudukan masyarakat Kawasan Pluit.(2019)

Nulty, P. (2020). Light As An Instrument Of Hope, diambil dari web : http:// www.designcurial.com/ news/ light-an-instrument-of-hope-7889683

Oldenburg, R. (1997). The Great, Good Place. Cambridge: Da Capro Press

PUPR, P. (2015). Peraturan garis sempadan sungai dan garis danau. Diunduh dari https://www.dsdan.go.id/mdocs-posts/permen-pupr-28-2015-ttg-penetapan-garissempadan- sungai-dan-garis-sempadan-danau.

Schreen, O. (2016). Why Great Architects Should Tell a Story (TED). Seminar TED.

Turkle, S. (2012). Connected But Alone. Seminar TED. ,www.cadmapper.co.id 